\title{
Kontribusi Pendidikan Islam dalam Menumbuhkan Kecerdasan Emosional
}

\author{
Alifia Wahyuni Choirun Nisa ${ }^{1}$, Ari Susandi ${ }^{2}$ \\ ${ }^{12}$ Sekolah Tinggi Agama Islam Muhammadiyah Probolinggo, Indonesia \\ 1alifiawahyuni641@gmail.com \\ 2pssandi87@gmail.com
}

\begin{abstract}
Abstrak:
Kecerdasan emosional merupakan konsep pendidikan yang belum banyak diperhatikan oleh pendidik dalam dunia pendidikan. Secara umum dunia pendidikan didominasi oleh konsep kecerdasan intelektual yang mencakup teori dan praktik. Dalam kaitannya dengan pendidikan Islam, kecerdasan emosional memiliki pengaruh yang signifikan untuk mewujudkan individu yang berilmu dan berakhlak mulia sesuai karakteristik ajaran Islam. Penelitian ini bertujuan untuk mengkaji kontribusi pendidikan Islam dalam menumbuhkan kecerdasan emosional yang meliputi konsep kecerdasan emosional menurut sudut pandang Islam serta strategi dan implementasi pendidikan Islam dalam menumbuhkan kecerdasan emosional. Penelitian ini menggunakan metode library research, yaitu metode penelitian yang dilakukan dengan mempelajari beberapa media atau sarana keilmuan seperti buku-buku, karya tulis ilmiah, jurnal, dan artikel untuk memecahkan suatu permasalahan tertentu. Permasalahan yang diteliti dalam penelitian ini meliputi bagaimana konsep kecerdasan emosional menurut sudut pandang Islam dan bagaimana strategi serta implementasi pendidikan Islam dalam menumbuhkan kecerdasan emosional. Adapun hasil dari penelitian ini yaitu mendeskripsikan konsep kecerdasan emosional menurut sudut pandang Islam, menguraikan strategi pendidikan Islam dalam menumbuhkan kecerdasan emosional dan menjelaskan implementasi pendidikan Islam dalam menumbuhkan kecerdasan emosional.
\end{abstract}

Kata Kunci: pendidikan Islam, kecerdasan emosional, anak

\section{Abstract:}

Emotional intelligence is an educational concept that has not been widely noticed by educators in the world of education. In general, the world of education is dominated by the concept of intellectual intelligence that includes theory and practice. In relation to Islamic education, emotional intelligence has a significant influence to realize individuals who are knowledgeable and noble in accordance with the characteristics of Islamic teachings. This research aims to examine the contribution of Islamic education in fostering emotional intelligence which includes the concept of emotional intelligence according to the Islamic point of view as well as the strategy and implementation of Islamic education in fostering emotional intelligence. This research uses library research method, which is a research method that is done by studying several media or scientific facilities such as books, scientific papers, journals, and articles to solve a particular problem. The problems studied in this study include how the concept of emotional intelligence according to the Islamic point of 
view and how the strategy and implementation of Islamic education in fostering emotional intelligence. The results of this study are describing the concept of emotional intelligence according to the Islamic point of view, outlining Islamic education strategies in fostering emotional intelligence and explaining the implementation of Islamic education in fostering emotional intelligence.

Keywords: Islamic education, emotional intelligence, children

\section{Pendahuluan}

Pada era universal (globalization) seperti masa ini menuntut perkembangan zaman beserta modernisasinya dalam segala bidang kehidupan, tak terkecuali pada bidang ilmu pengetahuan dan teknologi. Kemajuan teknologi dengan segala kecanggihannya telah banyak mempermudah sebagian besar aktivitas manusia. Hal ini merupakan implikasi dari kemajuan ilmu pengetahuan. Agar tidak terjadi ketimpangan antara kemajuan teknologi dengan ilmu pengetahuan, maka diperlukan langkah-langkah untuk mengimbanginya melalui kegiatan pendidikan yang tidak hanya mengedepankan aspek kognitif dan psikomotorik namun juga aspek afektif. Dengan demikian pendidikan tidak hanya mengunggulkan kecerdasan intelektual dan keterampilan praktis namun juga kecerdasan emosional.

Apabila kecerdasan emosional tersebut diabaikan maka dikhawatirkan akan terjadi kecacatan tertentu pada diri seseorang baik dalam keterampilan individual maupun sosialnya. Kecerdasan emosional erat kaitannya dengan kecerdasan intelektual. Kedua hal tersebut dipengaruhi oleh tingkat intelegensi. Menurut Robert J. Sternberg konsep intelegensi seseorang melingkupi tiga faktor kompetensi yaitu: (1) kompetensi problem solving (memecahkan masalah) menggunakan pikiran yang logis, (2) kompetensi verbal (kecakapan berbicara dengan baik dan jelas), dan (3) kompetensi sosial (kemampuan untuk beradaptasi dengan orang lain). Sedangkan faktor yang mempengaruhi intelegensi seseorang sebagaimana dikemukakan oleh Thurstone meliputi: kecakapan verbal dan kelancaran katakata, keterampilan pengindraan, serta kemampuan untuk mengingat dan menalar. ${ }^{1}$

Dewasa ini muncul pandangan yang mengatakan bahwa seseorang dengan tingkat intelegensi tinggi tidak menjamin keberhasilannya baik di sekolah maupun di masyarakat, sedangkan seseorang dengan tingkat intelegensi sedang-sedang saja menjadi sukses. Hal ini dipengaruhi oleh suatu faktor yang disebut kecerdasan emosional. Seseorang yang mengalami kecacatan pada kecerdasan emosionalnya, cenderung akan kesulitan dalam menerapkan keterampilan mengelola emosi sehingga sulit pula untuk menemukan perbaikan

${ }^{1}$ H C A Kistoro, "Kecerdasan Emosional Dalam Pendidikan Islam,” Jurnal Pendidikan Agama Islam XI, no. 1 (2014): 1-18. 
ataupun pencegahan dari permasalahan yang dihadapi. Sebaliknya, seseorang dengan kecerdasan emosional yang baik akan lebih terampil dalam mengelola emosi sehingga lebih mudah mengatasi permasalahan yang dihadapi.

Melalui pendidikan, seorang pendidik dituntut untuk dapat membina, mengarahkan, dan memenuhi kebutuhan emosional anak didik yang meliputi rasa kasih sayang, rasa aman (perlindungan), apresiasi (penghargaan), kesempatan belajar dan mengembangkan diri, serta mengaktualisasikan diri. Untuk memenuhi kebutuhan emosional tersebut, seorang pendidik harus mampu menyesuaikan pembelajaran emosional yang akan diberikan dengan usia dan tahap perkembangan anak didik. Dengan demikian pemenuhan kebutuhan emosional dapat berjalan dengan efektif.

Namun pada realitanya, kecerdasan emosional kurang begitu diperhatikan dalam praktik pendidikan. Dengan kata lain, tidak semua pendidik menyadari pentingnya kecerdasan emosional. Selama ini praktik pendidikan memberikan persepsi bahwa pendidikan selalu berpusat pada materi pembelajaran yang mengharuskan anak didik untuk memiliki kecakapan kognitif dan motorik, namun kurang memperhatikan pemenuhan kebutuhan emosional. Manajemen pendidikan seperti ini memang dapat menghasilkan produk pendidikan yang cerdas dalam menerapkan ilmu pengetahuan, terampil dalam menggunakan teknologi, dan dapat menyesuaikan diri dengan arus globalisasi, namun belum sesuai dengan tingkat perkembangan psikologi. ${ }^{2}$

Pendidikan Islam memberikan perhatian yang tinggi untuk menyikapi arus globalisasi. Menurut Arifin dalam Mulyadi, pendidikan Islam memiliki kewajiban untuk membina dan menuntun pertumbuhan serta perkembangan manusia sesuai dengan tahap kehidupan hingga mencapai potensi optimal, yaitu terbentuknya akhlak yang baik. $^{3}$ Kebanyakan orang yang berhasil di dunia ini mempunyai motivasi yang kuat yang mendorong tindakan-tindakan mereka. Mereka mengetahui dengan baik yang menjadi motivasinya dan memelihara motivasi tersebut dalam setiap tindakannya. ${ }^{4}$ Berdasarkan pernyataan tersebut pendidikan Islam juga memiliki pengaruh besar terhadap tumbuh kembang pendidikan dan ilmu pengetahuan. Hal ini dibuktikan dengan banyaknya karya cendekiawan muslim yang telah memberikan sumbangsih dan pemikirannya dalam dunia

2 Devy Habibi and Nur Khosiah, "Strategi Pemimpin Dalam Membangun Organisasi Multikultural Dalam Pendidikan," Imtiyaz: Jurnal Ilmu Keislaman 3, no. 2 (2019): 163-76, doi:10.46773/imtiyaz.v3i2.55.

${ }^{3}$ Mus Mulyadi, "Pentingnya Pembinaan Akhlak Bagi Anak Masa Pubertas," Jurnal Al-Ta'lim 13, no. 2 (2014): 263-74.

${ }^{4}$ Fikri Maulana, "Pendidikan Kewirausahaan Dalam Islam," IQ (Ilmu Al-Qur'an): Jurnal Pendidikan Islam 2, no. 01 (January 1, 2019): 30-44, doi:10.37542/IQ.V2I01.23.

156 | IQ (Ilmu Al-qur'an): Jurnal Pendidikan Islam| Volume 4 No. 022021 
pendidikan dan ilmu pengetahuan. Dalam korelasinya dengan kecerdasan emosional, pendidikan Islam juga memiliki andil untuk menumbuhkan, mengembangkan, membina, ataupun mengatasi permasalahan pendidikan yang berkaitan dengan kecerdasan emosional.

Pada mulanya, teori kecerdasan emosional berasal dari Barat dan belum terlihat keterkaitannya dengan ajaran Islam. Oleh karena itu, penting bagi peneliti untuk mengkaji kembali teori tersebut dalam perspektif Islam. Dengan demikian teori kecerdasan emosional tersebut dapat diaplikasikan untuk mengatasi problem yang terjadi dalam dunia pendidikan Islam. Melalui pendidikan Islam diharapkan akan terbentuk manusia dengan pribadi yang sempurna, yaitu manusia yang mampu mengendalikan seluruh emosi yang dimiliki sesuai dengan ajaran Islam, mampu menyeimbangkan kepentingan dunia dan akhirat, optimis, dan memiliki jiwa solidaritas yang tinggi.

Penelitian ini merupakan wujud replika dari penelitian sebelumnya yaitu penelitian Fenty Setiawati (2021) dan penelitian Andi Makmur Jaya Nur (2014). Penelitian Fenty Setiawati (2021) mengungkapkan tentang definisi dan fungsi kecerdasan emosional yang ditinjau dari sudut pandang Islam dengan merujuk pada Al-Qur'an serta menjelaskan peran pendidikan Islam dalam menumbuhkan kecerdasan emosional melalui pembinaan akhlak. Sedangkan Andi Makmur Jaya Nur (2014) dalam penelitiannya mengemukakan tentang konsep kecerdasan emosional meliputi pengertian dan fungsinya, pandangan Islam terhadap kecerdasan emosional, serta peran guru terhadap pengembangan kecerdasan emosional (EQ) dan kecerdasan spiritual (SQ).

Dengan demikian penelitian ini memiliki disimilaritas atau perbedaan dengan penelitian sebelumnya yaitu penelitian ini membahas tentang konsep kecerdasan emosional dalam perspektif Islam berdasarkan Al-Qur'an serta klasifikasinya yang ditinjau dari teori Barat, strategi yang dilakukan pendidikan Islam untuk menumbuhkan kecerdasan emosional yang dijelaskan berdasarkan usia dan tahap perkembangan manusia, serta implementasi pendidikan Islam dalam menumbuhkan kecerdasan emosional yang dijelaskan melalui konsep tazkiyatun nafs.

Berdasarkan disimilaritas dari penelitian sebelumnya, maka permasalahan yang diteliti meliputi: (1) Bagaimana konsep kecerdasan emosional menurut perspektif Islam? (2) Bagaimana strategi yang dilakukan dalam pendidikan Islam untuk menumbuhkan kecerdasan emosional? dan (3) Bagaimana implementasi pendidikan Islam dalam menumbuhkan kecerdasan emosional? Adapun tujuan dari penelitian ini yaitu untuk memahami konsep kecerdasan emosional menurut perspektif Islam dan memahami strategi serta implementasi pendidikan Islam dalam menumbuhkan kecerdasan emosional. 


\section{Tinjauan Tentang Pendidikan Islam}

Hukum Republik Indonesia telah menetapkan definisi pendidikan dalam UU. No. 20 Tahun 2003 mengenai Sistem Pendidikan Nasional yang menyatakan bahwa pendidikan merupakan upaya yang dilakukan dengan sadar serta terencana untuk menciptakan atmosfer belajar dan sistem pembelajaran dengan anak didik yang berperan aktif dalam meningkatkan kemampuan baik dari segi keimanan, penguasaan diri, karakter, dan keterampilan yang dibutuhkan dirinya, masyarakat, bangsa, serta Negara. ${ }^{5}$ Sedangkan definisi pendidikan Islam sebagaimana dikemukakan oleh Achmadi, yaitu segala upaya untuk membina, meningkatkan, dan memelihara sumber daya manusia agar seutuhnya sesuai dengan norma Islam. Pendapat tersebut didukung oleh Ahmad Tafsir yang mengatakan bahwa pendidikan Islam yaitu suatu ajaran yang diberikan dari pendidik kepada anak didik supaya mampu berkembang dengan optimal sesuai kaidah Islam. ${ }^{6}$ Berdasarkan definisi tersebut dapat disimpulkan bahwa pendidikan Islam merupakan suatu cara, proses, aktivitas, upaya, atau pembinaan yang dilaksanakan dengan sadar dan terencana untuk membentuk dan mengarahkan kepribadian anak didik agar sesuai tujuan dan kaidah Islam.

Menurut Al-Ghazali, pendidikan Islam memiliki dua tujuan utama yaitu pertama untuk membentuk insan yang paripurna dalam melaksanakan kewajiban taqarrub ilallah (mendekatkan diri kepada Allah) dan kedua untuk menggapai kebahagiaan baik di dunia maupun di akhirat. Melalui penggunaan ilmu pengetahuan, manusia dapat mencapai kesempurnaan yakni kebahagiaan hidup di dunia sebagai media untuk menjalankan taqarrub ilallah demi mencapai kebahagiaan hakiki di alam yang kekal (akhirat). ${ }^{7}$ Dengan demikian dapat disimpulkan bahwa pendidikan Islam bertujuan untuk menciptakan kepribadian muslim yang menerapkan ajaran Islam serta dapat mengoptimalkan seluruh kemampuan yang dimiliki baik dalam aspek jasmani, rohani, keilmuan, karakter/kepribadian, dan sosial sehingga dapat menunaikan kewajiban untuk mengabdi kepada Allah SWT.

\section{Tinjauan tentang Kecerdasan Emosional}

5 Dodi Ilham, "Menggagas Pendidikan Nilai Dalam Sistem Pendidikan Nasional," Didaktika: Jurnal Kependidikan 8, no. 3 (2019): 109-22.

${ }^{6}$ Lis Yulianti Syafrida Siregar, "Pendidikan Anak Dalam Islam," Jurnal Pendidikan Anak I, no. 2 (2016): 16-32.

${ }^{7}$ Miftahur Rohman and Hairudin, "Konsep Tujuan Pendidikan Islam Perspektif Nilai-Nilai Sosial Kultural," Al-Tadzkiyyah: Jurnal Pendidikan Islam 9, no. 1 (2018): 21-35, doi:10.24042/atjpi.v9i1.2603. 158 | IQ (Ilmu Al-qur'an): Jurnal Pendidikan Islam| Volume 4 No. 022021 
Istilah kecerdasan emosional dipopulerkan oleh jurnalis keilmuan berkebangsaan Inggris bernama Daniel Goleman. Menurut Goleman kecerdasan emosional adalah kemampuan, keahlian, keterampilan, dan akurasi seseorang dalam mengendalikan emosi dirinya ketika berinteraksi dengan orang lain di sekitarnya dengan memanfaatkan segenap potensi intelektual seperti memunculkan ide-ide (inisiatif), memiliki tenggang rasa (empati), mampu menyesuaikan diri (adaptasi), berkomunikasi dan menjalin kerja sama yang baik, serta mampu memberikan pengaruh terhadap orang lain (persuasi). ${ }^{8}$ Dengan demikian kecerdasan emosional yaitu keterampilan seseorang untuk mengidentifikasi dan mengendalikan emosi diri sehingga ia memiliki motivasi, kecakapan, dan keterampilan sosial dalam berinteraksi dengan lingkungan sekitarnya

Goleman menjelaskan bahwa perkembangan kecerdasan emosional sangat responsif terhadap dua faktor, yaitu pola didik orang tua di lingkungan keluarga dan pola didik guru di lingkungan sekolah. ${ }^{9}$ Orang tua di lingkungan keluarga berperan krusial dalam proses pembentukan dan pengembangan kecerdasan emosional anak. Aktivitas emosional yang berlangsung pada masa kanak-kanak akan terpaku pada diri seseorang dan terbawa hingga dewasa. Dengan demikian, apabila dalam suatu keluarga terjalin aktivitas emosional yang baik, maka hal tersebut akan sangat bermanfaat bagi anak dalam menerapkan kecerdasan emosionalnya di masa yang akan datang. Sedangkan di lingkungan sekolah untuk membina dan mengembangkan kecerdasan emosional anak, guru dituntut untuk memaksimalkan metode pengajaran dan melatih siswa agar memiliki jiwa sosial yang baik. Apabila kedua hal tersebut dijalankan dengan baik maka dapat mengajarkan anak untuk mengembangkan intelektualitas sebagai individu dan keterampilan dalam bersosial yang akan mempengaruhi kecerdasan emosional.

\section{Metode Penelitian}

Penelitian ini menggunakan metode penelitian daftar pustaka (library research), yakni penelitian yang menekuni bermacam rujukan keilmuan dan hasil penelitian terdahulu guna memperoleh landasan filosofi terkait permasalahan yang hendak diteliti. ${ }^{10}$ Pendekatan filosofi

${ }^{8}$ Rosmiyati Ramli and Nanang Prianto, "Peranan Guru Pendidikan Agama Islam Dalam Pembinaan Kecerdasan Emosional,” Jurnal Al-Ibrah VIII, no. 01 (2019): 14-29.

9 Wahid Khoirul Anam, "Hubungan Antara Kecerdasan Emosional Dengan Motivasi Belajar (Studi Kasus Di Madrasah Aliyah Al-MubaroK Uman Agung Kecamatan Bandar Mataram),” Dimar 2, no. 1 (2020): 94-108.

10 T. Mirzaqon and Budi Purwoko, "Studi Kepustakaan Mengenai Landasan Teori Dan Praktik Konseling Expressive Writing," Jurnal BK Unesa 8, no. 1 (2017). 
yang digunakan ialah analisis kualitatif deskriptif yang dilakukan dengan meneliti suatu fenomena tertentu yang diikuti dengan alur penjelas kemudian dijadikan suatu abstraksi dan kesimpulan. ${ }^{11}$ Pendekatan kualitatif juga dideskripsikan sebagai studi yang meneliti fenomena dan perilaku sosial sesuai fakta yang kemudian dijelaskan secara mendalam. ${ }^{12}$ Sehubungan dengan penggunaan metode library research, maka kewajiban peneliti yaitu mencari beragam materi tercatat yang berkaitan dengan masalah yang dicermati untuk memudahkan memperoleh informasi,

\section{Hasil Penelitian dan Pembahasan}

\section{Konsep Kecerdasan Emosional Menurut Perspektif Islam}

Sebelum menguraikan tentang konsep atau landasan filosofi tentang kecerdasan emosional dalam perspektif Islam, peneliti hendak mendeskripsikan konsep kecerdasan emosional menurut teori Barat seperti yang dikemukakan oleh Daniel Goleman dalam Desmita, yakni kecerdasan emosional diklasifikasikan menjadi lima komponen utama, yaitu mengidentifikasi emosi diri, mengendalikan emosi, motivasi diri, mengidentifikasi emosi orang lain, serta menjalin interaksi dengan orang lain. ${ }^{13}$

Pertama, mengidentifikasi emosi diri, yaitu kecakapan seseorang untuk mengenali serta memahami emosi dan pikirannya sendiri ketika berhubungan dengan orang lain. Kesadaran diri yang didukung oleh kepercayaan diri yang kuat akan memudahkan untuk berpikir rasional sehingga dapat mengatasi emosi yang bersifat negatif. Kedua, mengendalikan emosi, yaitu kemampuan seseorang untuk mengatur emosi supaya bernilai positif saat melaksanakan kewajiban, peka dengan kata hati, mampu mendahulukan kebutuhan sebelum keinginan, dan mampu menetralkan emosi negatif. Ketiga, motivasi diri, yakni kemampuan seseorang untuk memanfaatkan tekad dan ambisi yang kuat ketika mengarahkan diri agar sesuai tujuan, mengakomodasi pengambilan inisiatif, bertindak tepat guna, dan selalu optimis meskipun ditempa kegagalan atau kekalahan. Motivasi dengan emosi memiliki keterkaitan, yakni apabila emosi dapat menentukan perilaku seseorang, maka perilaku seseorang dapat mencerminkan bagaimana emosinya. Keempat, mengidentifikasi emosi orang lain, yakni kecakapan seseorang untuk bersimpati pada orang lain, mencoba

11 Wiwin Yuliani, "Metode Penelitian Deskriptif Kualitatif Dalam Perspektif Bimbingan Dan Konseling,” QUANTA 2, no. 2 (2018): 83-91, doi:10.22460/q.v1i1p1-10.497.

12 Ari Susandi, Reza Hilmy Luayyin, and Aries Dirgayunita, “Aktualisasi Diri Untuk Mengurangi Perilaku Bullying Pada Anak,” Jurnal Visi Ilmu Pendidikan 13, no. 2 (2021): 72-83, doi:10.26418/jvip.v13i2.45698.

${ }^{13}$ Desmita, Psikologi Perkembangan, Cet. Ke-7 (Bandung: PT. Remaja Rosdakarya, 2012). 160 | IQ (Ilmu Al-qur'an): Jurnal Pendidikan Islam| Volume 4 No. 022021 
memahami pemikiran ataupun pendapat mereka, membangun kepercayaan satu sama lain, serta beradaptasi. Untuk mengidentifikasi emosi orang lain, tidak terbatas melalui kata-kata namun juga pesan nonverbal misalnya intonasi bicara, mimik muka, dan bahasa tubuh. Kelima, menjalin interaksi dengan orang lain, yakni kecakapan seseorang untuk berinteraksi dengan orang-orang di sekitarnya, cermat dalam mengenali situasi, dapat bertindak bijaksana, serta memiliki keterampilan sosial untuk mempengaruhi orang lain.

Untuk menggambarkan kecerdasan emosional menurut perspektif Islam, Al-Qur'an telah terlebih dahulu menguraikan tentang emosi sebagaimana disebutkan dalam QS. AlQashas 28:21 tentang emosi takut, QS. Al-A'raf 7:150 tentang emosi marah, QS. Al-Ahzab 33:47 tentang emosi gembira, QS. An-Nisa' 4:19 tentang emosi benci, QS. Ali Imron 3:14 tentang emosi cinta, QS. Yusuf 12: 8-9 tentang emosi cemburu, QS. Thaha 20:40 tentang emosi sedih, QS. Al-Baqarah 2:109 tentang emosi dengki, QS. Al-Maidah 5:30-31 tentang emosi penyesalan, dan ayat lainnya yang mempresentasikan tentang kondisi emosi. ${ }^{14}$

Di dalam Al-Qur'an kecerdasan emosional cenderung dipresentasikan melalui keterkaitan antara nafs dan qalbu. Nafs bermakna keseluruhan potensi pada diri manusia yang mendorong terbentuknya perilaku. Sedangkan qalbu diartikan sebagai media untuk menampung hasil pembelajaran berupa rasa kasih sayang, keimanan, dan ketaqwaan. ${ }^{15}$ Hati (qalbu) merupakan pusat pendidikan akhlak. Oleh karena itu, kecerdasan emosional dalam Islam erat kaitannya dengan pendidikan akhlak sehingga juga disebut dengan istilah kognitif qalbiyah, yaitu kemampuan hati (qalbu) dalam mengendalikan segala perilaku (nafs). Untuk membentuk kognitif qalbiyah yang baik maka harus dilatih dengan dididik, diperbaiki, diluruskan, dan diberi perhitungan serta teguran.

Dengan demikian konsep kecerdasan emosional menurut perspektif Islam ialah keterkaitan antara hati (qalbu) dengan perilaku (nafs). Apabila pada diri seseorang terdapat hati dan perilaku yang berkorelasi dengan positif, maka dapat mewujudkan potensi emosional yang positif pula seperti munculnya sikap beriman dan bertaqwa, toleransi, empati, simpati, termotivasi, serta mampu berinteraksi, berkomunikasi, dan beradaptasi dengan baik.

\section{Strategi Pendidikan Islam dalam Menumbuhkan Kecerdasan Emosional}

14 Anisatul Masruroh, "Konsep Kecerdasan Emosional Dalam Perspektif Pendidikan Islam," MUDARRISA: Journal of Islamic Education 6, no. 1 (2015): 61, doi:10.18326/mdr.v6i1.759.

${ }^{15}$ Fenty Setiawati, "Peranan Pendidikan Islam Dalam Menumbuhkan Kecerdasan Emosional," Nizamul 'Ilmi: Jurnal Manajemen Pendidikan Islam (JMPI) 6, no. 1 (2021): 21-30. 
Kata strategi memiliki definisi yaitu langkah-langkah atau tahapan yang dibuat dengan terstruktur berdasarkan metode tertentu. ${ }^{16}$ Dengan demikian strategi pendidikan Islam merupakan rangkaian perilaku pendidikan yang disusun secara sistematis dan terencana yang bertujuan untuk menumbuhkan dan membentuk nilai-nilai moral Islami pada kepribadian anak didik. Dalam upayanya untuk menumbuhkan kecerdasan emosional, strategi pendidikan Islam dibedakan menjadi tiga lingkup yaitu lingkup lingkungan keluarga, dan masyarakat.

Lingkungan keluarga adalah lingkungan pertama bagi anak dalam menerima pendidikan sebelum di lingkungan yang lain. ${ }^{17}$ Dalam hal ini, pendidikan Islam yang diberikan oleh orang tua dalam keluarga memiliki peran krusial dan fundamental untuk menumbuhkembangkan fitrah keberagamaan anak. Upaya menumbuhkan kecerdasan emosional melalui pendidikan Islam di lingkungan keluarga erat kaitannya dengan proses penanaman keimanan dan pengembangan fitrah anak yang dapat dilakukan sesuai usia dan tahap perkembangan anak.

Saat berusia 0-2 tahun anak berada pada tahap asuhan, yaitu tahapan di mana anak belum mempunyai daya kesadaran dan intelektual sehingga hanya dapat menyerap impuls biologis melalui pemberian ASI dan impuls psikologis melalui belaian kasih seorang ibu. Pendidikan Islam yang dapat diterapkan pada tahap ini di antaranya: (1) Saat anak baru lahir, orang tua mengumandangkan azan di telinga kanan dan iqamah di telinga kiri dengan tujuan mengenalkan anak pada pencipta-Nya sedari bayi, (2) Melaksanakan aqiqah berupa dua kambing bagi anak laki-laki dan satu kambing bagi anak perempuan sebagai perwujudan rasa syukur orang tua kepada Allah SWT atas kelahiran anaknya, juga sebagai pengharapan orang tua agar anaknya tumbuh sebagai anak yang saleh, (3) Memberikan nama yang baik dengan harapan dapat terbentuk perilaku yang baik pada diri anak, (4) Memberikan ASI sampai anak berusia dua tahun. Selain untuk memenuhi kebutuhan bayi, pemberian ASI juga berguna untuk menumbuhkan keakraban serta menunjukkan rasa cinta dan kasih ibu kepada bayinya, dan (5) Membiasakan pola hidup yang sehat, bersih, dan suci serta memberikan makanan yang halal kepada anak sejak usia dini.

Selanjutnya pada usia 3-12 tahun anak memasuki tahap kanak-kanak. Pada tahap ini suatu pendidikan berperan untuk mengembangkan kemampuan jasmani dan rohani anak melalui pembinaan dan pelatihan sesuai dengan bakat dan minat yang dimiliki anak.

\footnotetext{
${ }^{16}$ Nasaruddin, "Optimalisasi Pendidikan Islam Dalam Menumbuhkan Kecerdasan Emosional," Jurnal Ilmiah "Kreatif" 18, no. 1 (2020): 27-46.

${ }^{17}$ Sugiharsono Sutardi, "Harmoni Sosial : Jurnal Pendidikan IPS Volume 3, No 2 , September 2016 ( 188-198 ) Online : Http://Journal.Uny.Ac.Id/Index.Php/Hsjpi Harmoni Sosial : Jurnal Pendidikan IPS," Harmoni Sosial: Jurnal Pendidikan IPS 3, no. 2 (2016): 188-98.

162 | IQ (Ilmu Al-qur'an): Jurnal Pendidikan Islam| Volume 4 No. 022021
} 
Penerapan pendidikan Islam dilakukan dengan menjelaskan perintah-perintah dan laranganlarangan yang ada dalam agama. Proses pendidikan Islam dapat dilakukan dengan penuh kasih sayang melalui pemberian cerita sejarah atau kisah-kisah teladan yang disajikan dengan menarik. Hal ini bertujuan untuk mengenalkan anak pada hukum-hukum Islam serta memupuk pembiasaan yang baik sedari dini.

Berlanjut saat berusia 12-20 tahun anak memasuki tahap pencarian jati diri atau disebut juga periode tamyiz, yakni tahapan saat anak mulai memiliki kemampuan untuk membedakan antara yang haq dengan yang bathil. Periode tamyiz juga disebut baligh, yakni periode saat anak telah memiliki kewajiban memikul beban taklif (kewajiban yang dibebankan oleh Allah SWT kepada hamba-Nya yang mencapai umur baligh). Saat anak berusia tujuh sampai sepuluh tahun, praktik pendidikan Islam dilakukan dengan persuasi (paksaan verbal) oleh orang tua. Namun saat anak memasuki usia di atas sepuluh tahun, orang tua dianjurkan mennggunakan paksaan fisik.

Tahap berikutnya pada usia 20-30 tahun anak memasuki tahap kematangan jati diri atau telah beranjak dewasa. Praktik pendidikan Islam dapat dilakukan melalui pembinaan untuk menentukan pasangan hidup dengan mempertimbangkan aspek religiusitas, finansial, lingkungan sosial, dan lain sebagainya. Tahap selanjutnya yaitu saat berusia 30 tahun sampai meninggal (tahap tua / syuyukh). Praktik pendidikan Islam dapat dilakukan dengan menunjukkan rasa peduli dan rendah hati untuk senantiasa mengingatkan mereka apabila lupa dengan beban taklifnya serta menyeru untuk memperbanyak amal jariyah dengan menyedekahkan harta bendanya di jalan agama sebelum mencapai akhir hayatnya.

Selain melalui tahapan-tahapan tersebut, praktik pendidikan Islam dalam lingkungan keluarga juga dapat dilakukan melalui peran partisipasi orang tua sebagai contoh atau teladan yang baik bagi anaknya. Jalaluddin dalam Nasaruddin mengungkapkan beberapa upaya lain yang dapat dilakukan orang tua untuk menunjang pembinaan ajaran agama kepada anak yakni dengan mewujudkan generasi keluarga Rabbani (keluarga yang mengagungkan ajaran Islam demi menggapai ridho Allah SWT) seperti membiasakan anak untuk menegakkan sholat, menjalankan puasa, menunaikan zakat, berdzikir, berdoa ketika hendak ataupun selesai melakukan sesuatu, bersyukur, dan sebagainya. ${ }^{18}$

Upaya menumbuhkan kecerdasan emosional juga dapat dilakukan di lingkungan sekolah. Sebagai lembaga pendidikan formal sekolah memiliki berbagai program terstruktur yang berperan krusial dalam proses tumbuh kembang potensi anak didik melalui pengajaran

${ }^{18}$ Nasaruddin, “Optimalisasi Pendidikan Islam Dalam Menumbuhkan Kecerdasan Emosional.” 
dan pelatihan. ${ }^{19}$ Aspek pertama yang diperhatikan di lingkungan sekolah adalah kurikulum pendidikan. Dewasa ini, muatan kurikulum pendidikan Islam di sekolah didominasi oleh aspek hafalan yang hanya mengedepankan kemmapuan kognitif. Hal ini hendaknya segera diformulasikan kembali dengan lebih memberikan perhatian pada aspek praktik untuk menstimulasi kemampuan motorik anak didik serta mengkolaborasikan keduanya untuk membentuk kemampuan afektif. Dengan demikian pendidikan Islam di sekolah menjadi lebih bermakna karena tidak semata-mata mengedepankan ilmu teoritis, namun juga keterampilan praktis serta pembentukan moral yang baik.

Aspek kedua yang diperhatikan yaitu metode pembelajaran. Metode pembelajaran agama di sekolah sebaiknya didominasi dengan praktik langsung melalui pembinaan iman dan taqwa. Misalnya dalam mengajarkan materi rukun Islam tidak hanya berorientasi pada aspek hafalan, namun juga mengimplementasikannya melalui praktik nyata. Begitu pula pada materi pembelajaran tentang etika sosial atau pemenuhan diri terhadap hak orang lain seperti kebersihan, kejujuran, disiplin, tanggung jawab, toleransi, menepati janji, dan lain sebagainya hendaknya tidak sekadar untuk dihafal, namun juga dipraktikkan dalam kehidupan.

Tohirin dalam Nasaruddin mengungkapkan bahwa terdapat berbagai cara yang dapat diterapkan untuk memupuk nilai-nilai agama di sekolah, antara lain: (1) mengajak anak mengunjungi panti asuhan sebagai implementasi dari pembelajaran surat Al-Ma'un, (2) membentuk pembiasaan yang baik melalui kisah-kisah teladan dalam Al-Qur'an dan hadits maupun kisah ulama, (3) mewujudkan nila-nilai Islam dalam praktik, dan (4) melatih anak didik untuk peduli terhadap lingkungan sekitar guna membentuk kehidupan sosial yang baik. $^{20}$

Aspek ketiga yang diperhatikan yaitu guru. Dalam perannya sebagai pendidik, guru mempunyai kewajiban untuk mengembangkan kecerdasan emosionalnya sendiri serta kecerdasan emosional siswanya. Adanya kolaborasi yang baik antara guru dan siswa dalam proses pembelajaran, dapat menjadi media untuk saling memenuhi kebutuhan emosional masing-masing melalui sikap peduli, saling menghormati, menghargai, dan menyayangi. Zakiah Daradjat dalam Nasaruddin mengungkapkan bahwa seorang guru diharuskan memiliki beberapa karakteristik yaitu: (1) memiliki kepribadian yang baik (berakhlak mulia), (2) menguasai bidang keilmuan yang diampu, dan (3) menguasai bidang keilmuan lain yang

19 Nafisa Feriana Feli and Syaiful Islam, "Implementasi Multicultural Based Learning Dalam Meningkatkan Prestasi Siswa," Jurnal MUDARRISUNA: Media Kajian Pendidikan Agama Islam 9, no. 1 (2019): 152-69, doi:10.22373/jm.v9i1.4469.

${ }^{20}$ Nasaruddin, "Optimalisasi Pendidikan Islam Dalam Menumbuhkan Kecerdasan Emosional." 164 | IQ (Ilmu Al-qur'an): Jurnal Pendidikan Islam| Volume 4 No. 022021 
dapat mendukung pengembangan potensinya dalam proses pembelajaran. Di samping itu, untuk menumbuhkan kecerdasan emosional di sekolah, proses pembelajaran agama Islam harus dapat memanifestasikan tujuan pendidikan seperti melatih siswa untuk meningkatkan rasa tanggung jawab, mandiri, menghormati dan menghargai diri sendiri, peduli dan bertoleransi, serta mampu beradaptasi. ${ }^{21}$

Kecerdasan emosional juga dapat tumbuh di lingkungan masyarakat. Lingkungan masyarakat yaitu lingkungan yang terdapat sekumpulan orang dalam suatu wilayah saling berinteraksi satu sama lain dan melakukan sesuatu secara bersama. ${ }^{22}$ Kondisi interaksi sosial yang terjadi di lingkungan masyarakat dapat mempengaruhi proses pembentukan kesadaran beragama pada diri anak yang nantinya juga mempengaruhi perkembangan kecerdasan emosionalnya. Faktor yang dapat mempengaruhi kecerdasan emosional anak di lingkungan masyarakat di antaranya yaitu media massa, teman bermain, teknologi, kegiatan sosial di masyarakat, dan ragam kehidupan tetangga. Di lingkungan masyarakat, anak cenderung berinteraksi dengan teman sebayanya. Namun di samping itu, tidak menutup kemungkinan anak juga mencontoh perilaku orang dewasa di sekitarnya yang mana hal ini juga dapat berperngaruh terhadap perkembangan pandangan moral dan tingkah laku anak. Dengan demikian dapat dikatakan bahwa kualitas pribadi orang dewasa dapat mempengaruhi kecerdasan emosional anak.

Nasaruddin mengungkapkan bahwa di lingkungan masyarakat pribadi orang dewasa dapat dikatakan berkualitas baik dan kondusif bagi perkembangan kesadaran beragama serta kecerdasan emosional anak apabila mereka berperilaku sebagai berikut: (1) memiliki kesadaran untuk taat dalam menjalankan kewajiban beragama, (2) menjalin silaturahmi, jujur, dan tolong-menolong (3) membentuk majelis ta'lim sebagai sarana memperdalam keagamaan di lingkungan masyarakat, dan (4) membiasakan diri dengan perilaku yang terpuji sesuai ajaran agama dan norma masyarakat serta menjauhkan dari perilaku yang tercela. ${ }^{23}$

Dengan demikian untuk menumbuh kembangkan kecerdasan emosional, pendidikan Islam memiliki strategi yaitu adanya peran aktif dari pendidik dalam membina, membimbing, dan mengarahkan pola pikir serta perilaku dan sikap anak sehingga dapat terbentuk kecerdasan emosional yang baik sesuai ajaran Islam. Kata pendidik di sini tidak hanya

21 Ibid.

${ }^{22}$ Ois Dian Tri Kusumawati, Agus Wahyudin, and Subagyo, "Pengaruh Pola Asuh, Lingkungan Masyarakat, Dan Kedisiplinan Belajar Terhadap Hasil Belajar Siswa SD Kecamatan Bandungan," Educational Management 6, no. 2 (2017): 87-94.

${ }^{23}$ Nasaruddin, “Optimalisasi Pendidikan Islam Dalam Menumbuhkan Kecerdasan Emosional.” 
ditujukan pada peran guru di sekolah, namun juga partisipasi orang tua di keluarga, dan warga masyarakat.

\section{Implementasi Pendidikan Islam dalam Menumbuhkan Kecerdasan Emosional}

Implementasi merupakan aktivitas yang ditekankan pada terbentuknya tindakan, aktivitas, kegiatan, atau cara kerja suatu sistem. ${ }^{24}$ Kata cara kerja atau disebut juga mekanisme di sini memiliki pengertian yaitu kegiatan yang dilakukan dengan terencana dan sungguh-sungguh serta mengacu pada suatu aturan tertentu guna mencapai tujuan yang diinginkan. $^{25}$ Untuk menumbuhkan kecerdasan emosional, pendidikan Islam diimplementasikan melalui pembinaan karakter atau pendidikan akhlak. Dalam upaya membentuk pendidikan akhlak, dibutuhkan penyelenggara pendidikan yang harus mampu berperan sebagai teladan, contoh, atau panutan yang baik bagi anak didik.

Anshari dalam Setiawati mengungkapkan bahwa pendidikan Islam merupakan upaya pembinaan yang dilakukan oleh pendidik kepada anak didik untuk mengembangkan potensi jiwa (akhlak/karakter) serta mengembangkan potensi raga melalui bahan ajar, metode, peralatan, ataupun sarana prasarana yang sesuai dengan ajaran Islam. ${ }^{26}$ Sedangkan Yusuf AlQardawi dalam Rakim menyatakan bahwasanya pendidikan manusia yang seutuhnya ialah pendidikan yang berorientasi pada akal, hati, jasmani, rohani, akhlak, dan keterampilan. ${ }^{27}$ Berdasarkan hal tersebut, pendidikan Islam berupaya untuk membentuk kehidupan yang baik serta mengembangkan potensi akal, jiwa, dan hati.

Implementasi pendidikan Islam untuk mengembangkan potensi akal dilakukan melalui pemberian pelajaran berupa teori untuk menstimulasi akal pikiran serta pelatihan penggunaan teknologi untuk membentuk keterampilan praktis. Sedangkan untuk mengembangkan potensi jiwa dan hati dilakukan melalui penyucian hati nurani (tazkiyatun nafs) agar terhindar dari segala emosi negatif yang mendorong terbentuknya akhlak tercela. Oleh karena itu, tazkiyatun nafs yang didukung dengan pembiasaan diri yang baik dapat mendorong terbentuknya akhlak terpuji. Tazkiyatun nafs berkaitan dengan tingkat keimanan dan ketaqwaan seseorang atau dalam frasa lain dapat dikatakan bahwa kualitas iman dan taqwa seseorang dapat mencerminkan bagaimana keadaan emosionalnya yang nantinya juga

${ }^{24}$ T. Prasetyo Hadi Atmoko, "Implementasi Kebijakan Desa Budaya Dalam Melestarikan Budaya Lokal Di Desa Sendangmulyo, Minggir, Sleman,” Jurnal Media Wisata 16, no. 1 (2018): 662-73.

${ }^{25}$ Cepi Setiawan and Rinawati, "Implementasi Aplikasi Peminjaman Dan Pembayaran Angsuran Pada BPR Kabupaten Bandung,” Jurnal Computech \& Bisnis 9, no. 1 (2015): 37-47.

${ }^{26}$ Setiawati, "Peranan Pendidikan Islam Dalam Menumbuhkan Kecerdasan Emosional."

27 Rokim, "Sinergi Hubungan Pendidikan Akal, Hati Dan Jasmani Dalam Perspektif Hamka," PANCAWAHANA: Jurnal Studi Islam 13, no. 2 (2018): 57-65.

166 | IQ (Ilmu Al-qur'an): Jurnal Pendidikan Islam| Volume 4 No. 022021 
akan menentukan baik atau buruk perilakunya. Dalam kaitannya dengan kecerdasan emosional tazkiyatun nafs berperan sebagai pendukung pembinaan akhlak. Adapun metode tazkiyatun nafs yang dapat dilakukan untuk meningkatkan kualitas akhlak yaitu melalui pendidikan jiwa dan pelatihan jiwa.

Hasballah menyatakan bahwa metode pendidikan jiwa merupakan proses pembinaan yang dilakukan untuk menahan, melawan, dan mengalihkan hawa nafsu serta menggantinya dengan membiasakan dan mengutamakan akhlak terpuji. ${ }^{28}$ Menurut Abuddin Nata akhlak terpuji juga disebut sebagai akhlak Islami, yaitu fitrah manusia untuk melakukan sesuatu dengan sengaja yang sesuai dengan ajaran Islam. ${ }^{29}$ Adapun contoh implementasi pendidikan Islam dalam membina akhlak Islami di antaranya dengan melatih diri untuk mengerjakan segala sesuatu semata-mata mengharap ridho Allah (ikhlas), berserah diri kepada Allah setelah melakukan suatu usaha (tawakkal), tetap tangguh saat menghadapi cobaan atau musibah (sabar), mampu mengerjakan sesuatu sesuai dengan kadar, tempat, atau kapasitasnya (adil), serta menjauhkan diri dari perbuatan yang keji seperti dusta, aniaya, berburuk sangka, kikir, putus asa, mengadu domba, dan lain sebagainya.

Sedangkan metode pelatihan jiwa ialah suatu proses untuk melatih diri supaya terbiasa mengerjakan sesuatu yang pada awalnya dianggap beban dan memberatkan akhirnya menjadi sebuah kebiasaan yang baik. ${ }^{30}$ Metode ini akan berjalan efektif apabila dalam pembinaannya seorang pendidik mampu berupaya memberikan pemahaman tentang sebabakibat mengapa harus berbuat hal yang baik. Pemahaman tersebut harus dipastikan tidak hanya diterima oleh akal, namun juga meresap ke dalam hati sehingga pelatihan dan pembinaan yang diajarkan dapat terealisasikan dengan baik melalui wujud pembiasaan akhlak terpuji.

\section{Kesimpulan}

Berdasarkan uraian di atas dapat disimpulkan bahwa:

1. Kecerdasan emosional menurut perspektif Islam merupakan hubungan antara hati dengan perilaku manusia yang erat kaitannya dengan pendidikan akhlak. Dengan demikian apabila baik isi hati seseorang, maka akan baik pula akhlak atau perilakunya karena pada dasarnya hati berperan sebagai kemudi dalam berinteraksi.

${ }^{28}$ Zamaksyari Hasballah, Rijal Sabri, and Abu Nasir, "Konsep Tazkiyatun Nafs (Studi Pendidikan Akhlak Dalam Alquran Surat Asy-Syams 7-10)," Sabilarrasyad III, no. 02 (2018): 38-52.

${ }^{29}$ Abuddin Nata, Perspektif Islam Tentang Strategi Pembelajaran, 1st ed. (Jakarta: Kencana Prenada Media Group, 2011).

${ }^{30}$ Hasballah, Sabri, and Nasir, "Konsep Tazkiyatun Nafs (Studi Pendidikan Akhlak Dalam Alquran Surat Asy-Syams 7-10).” 
2. Pendidikan Islam memiliki strategi khusus untuk menumbuhkan kecerdasan emosional, yakni melalui suatu peran aktif yang dilakukan oleh pendidik baik orang tua, guru, maupun warga masyarakat yang bersama-sama bersinergi dalam mengenalkan dan mengajarkan nilai-nilai Islam kepada anak sedari dini.

3. Dalam implementasinya untuk menumbuhkan kecerdasan emosional, pendidikan Islam dilakukan dengan mengembangkan potensi akal melalui pembinaan keterampilan dan penggunaan teknologi, serta mengembangkan potensi jiwa dan hati melalui tazkiyatun nafs (penyucian nurani) agar terhindar dari akhlak yang tercela. Tazkiyatun nafs merupakan komponen pendukung dalam pembinaan akhlak yang dapat dilakukan dengan metode pendidikan jiwa dan pelatihan jiwa. Kedua metode tersebut sejatinya memiliki kesamaan yaitu untuk membentuk pribadi manusia yang membiasakan berakhlak mulia sesuai ajaran Islam.

\section{Saran}

Penulis menyadari bahwa penelitian ini masih perlu disempurnakan oleh sebab itu penulis berharap kepada pembaca yang budiman maupun reviewer dalam penelitian selanjutnya untuk mengkaji kembali dengan tidak mengurangi, memalsukan, ataupun menghilangkan hasil penelitian ini beserta sumber yang tertera.

\section{Daftar Pustaka}

Anam, Wahid Khoirul. "Hubungan Antara Kecerdasan Emosional Dengan Motivasi Belajar (Studi Kasus Di Madrasah Aliyah Al-MubaroK Uman Agung Kecamatan Bandar Mataram).” Dimar 2, no. 1 (2020): 94-108.

Atmoko, T. Prasetyo Hadi. "Implementasi Kebijakan Desa Budaya Dalam Melestarikan Budaya Lokal Di Desa Sendangmulyo, Minggir, Sleman.” Jurnal Media Wisata 16, no. 1 (2018): 662-73.

Desmita. Psikologi Perkembangan. Cet. Ke-7. Bandung: PT. Remaja Rosdakarya, 2012.

Feli, Nafisa Feriana, and Syaiful Islam. "Implementasi Multicultural Based Learning Dalam Meningkatkan Prestasi Siswa." Jurnal MUDARRISUNA: Media Kajian Pendidikan Agama Islam 9, no. 1 (2019): 152-69. doi:10.22373/jm.v9i1.4469.

Habibi, Devy, and Nur Khosiah. "Strategi Pemimpin Dalam Membangun Organisasi Multikultural Dalam Pendidikan.” Imtiyaz: Jurnal Ilmu Keislaman 3, no. 2 (2019): 16376. doi:10.46773/imtiyaz.v3i2.55. 
Hasballah, Zamaksyari, Rijal Sabri, and Abu Nasir. "Konsep Tazkiyatun Nafs (Studi Pendidikan Akhlak Dalam Alquran Surat Asy-Syams 7-10).” Sabilarrasyad III, no. 02 (2018): 38-52.

Ilham, Dodi. "Menggagas Pendidikan Nilai Dalam Sistem Pendidikan Nasional." Didaktika: Jurnal Kependidikan 8, no. 3 (2019): 109-22.

Kistoro, H C A. "Kecerdasan Emosional Dalam Pendidikan Islam.” Jurnal Pendidikan Agama Islam XI, no. 1 (2014): 1-18.

Kusumawati, Ois Dian Tri, Agus Wahyudin, and Subagyo. "Pengaruh Pola Asuh, Lingkungan Masyarakat, Dan Kedisiplinan Belajar Terhadap Hasil Belajar Siswa SD Kecamatan Bandungan.” Educational Management 6, no. 2 (2017): 87-94.

Masruroh, Anisatul. "Konsep Kecerdasan Emosional Dalam Perspektif Pendidikan Islam.” MUDARRISA: Journal of Islamic Education 6, no. 1 (2015): 61. doi:10.18326/mdr.v6i1.759.

Maulana, Fikri. "Pendidikan Kewirausahaan Dalam Islam." IQ (Ilmu Al-Qur'an): Jurnal Pendidikan Islam 2, no. 01 (January 1, 2019): 30-44. doi:10.37542/IQ.V2I01.23.

Mirzaqon, T., and Budi Purwoko. "Studi Kepustakaan Mengenai Landasan Teori Dan Praktik Konseling Expressive Writing.” Jurnal BK Unesa 8, no. 1 (2017).

Mulyadi, Mus. "Pentingnya Pembinaan Akhlak Bagi Anak Masa Pubertas.” Jurnal Al-Ta'lim 13, no. 2 (2014): 263-74.

Nasaruddin. "Optimalisasi Pendidikan Islam Dalam Menumbuhkan Kecerdasan Emosional.” Jurnal Ilmiah “Kreatif” 18, no. 1 (2020): 27-46.

Nata, Abuddin. Perspektif Islam Tentang Strategi Pembelajaran. 1st ed. Jakarta: Kencana Prenada Media Group, 2011.

Ramli, Rosmiyati, and Nanang Prianto. "Peranan Guru Pendidikan Agama Islam Dalam Pembinaan Kecerdasan Emosional.” Jurnal Al-Ibrah VIII, no. 01 (2019): 14-29.

Rohman, Miftahur, and Hairudin. "Konsep Tujuan Pendidikan Islam Perspektif Nilai-Nilai Sosial Kultural." Al-Tadzkiyyah: Jurnal Pendidikan Islam 9, no. 1 (2018): 21-35. doi:10.24042/atjpi.v9i1.2603.

Rokim. "Sinergi Hubungan Pendidikan Akal, Hati Dan Jasmani Dalam Perspektif Hamka." PANCAWAHANA: Jurnal Studi Islam 13, no. 2 (2018): 57-65.

Setiawan, Cepi, and Rinawati. "Implementasi Aplikasi Peminjaman Dan Pembayaran Angsuran Pada BPR Kabupaten Bandung.” Jurnal Computech \& Bisnis 9, no. 1 (2015): $37-47$.

Setiawati, Fenty. "Peranan Pendidikan Islam Dalam Menumbuhkan Kecerdasan Emosional." IQ (Ilmu Al-qur'an): Jurnal Pendidikan Islam| Volume 4 No. 022021 | 169 
Alifia Wahyuni Choirun Nisa, Ari Susandi, Devy Habibi Muhammad

Nizamul 'Ilmi: Jurnal Manajemen Pendidikan Islam (JMPI) 6, no. 1 (2021): 21-30.

Siregar, Lis Yulianti Syafrida. "Pendidikan Anak Dalam Islam.” Jurnal Pendidikan Anak I, no. 2 (2016): 16-32.

Susandi, Ari, Reza Hilmy Luayyin, and Aries Dirgayunita. "Aktualisasi Diri Untuk Mengurangi Perilaku Bullying Pada Anak.” Jurnal Visi Ilmu Pendidikan 13, no. 2 (2021): 72-83. doi:10.26418/jvip.v13i2.45698.

Sutardi, Sugiharsono. "Harmoni Sosial : Jurnal Pendidikan IPS Volume 3 , No 2 , September 2016 ( 188-198 ) Online: Http://Journal.Uny.Ac.Id/Index.Php/Hsjpi Harmoni Sosial : Jurnal Pendidikan IPS.” Harmoni Sosial: Jurnal Pendidikan IPS 3, no. 2 (2016): 18898.

Yuliani, Wiwin. "Metode Penelitian Deskriptif Kualitatif Dalam Perspektif Bimbingan Dan Konseling." QUANTA 2, no. 2 (2018): 83-91. doi:10.22460/q.v1i1p1-10.497. 